\title{
The influence of natural organic matter on the adsorption properties of mineral particles in lake water
}

\author{
By Peter Baccini ${ }^{1}$ ), Erwin Grieder ${ }^{1}$ ), Ruth Stierli ${ }^{1}$ ) and Sabine Goldberg ${ }^{2}$ ) \\ 1) Swiss Federal Institute for Water Resources and Water Pollution Control (EAWAG), CH-6047 \\ Kastanienbaum, Switzerland \\ 2) University of California Riverside, Department of Soil and Environmental Sciences, Riverside, \\ CAL 92521, USA
}

Manuscript received on 23 February 1982

\begin{abstract}
The adsorption characteristics of sediment particles from a prealpine Swiss lake were compared with those of $\gamma$-aluminum oxide. Under lake water conditions, i.e. with particle concentration of $2-16 \mathrm{mg} / 1$ and DOC concentrations of $1-4 \mathrm{mg} / \mathrm{l}$ at $\mathrm{pH}=8$, the adsorption of copper, zine and orthophosphate is reduced significantly by the presence of natural organic matter (NOM). It is postulated that the binding sites of the natural mineral surfaces are occupied almost completely by NOM under natural conditions. A simple ligand exchange model can explain the observed phenomena.
\end{abstract}

\section{Introduction}

The flux of particulate minerals within a lake is one important transport path for most elements and substances passing through this ecosystem. The physicál and chemical nature of such particles depends primarily on the biogeochemical processes taking place in the catchment area of the lake. Entering the lake they experience a particle size fractionation whose extent is dependent on the hydrodynamic and orographic properties of the receiving system. Secondary chemical changes might take place on the surface of these particles due to a partially new physicochemical environment (e.g. changes in $\mathrm{pH}, \mathrm{pE}$, ionic strength, temperature, etc.). Therefore surface properties of such particles are considered to play a key role in the distribution of essential components within a water column of a lake. The particle surface can be a sink or a source for ions and uncharged substances.

In many laboratory experiments adsorption properties of chemically well-defined surfaces (e.g. aluminium oxide, quartz, rutile) have been studied to develop models for the more heterogenous surfaces found in nature and to predict their role in aquatic systems (e.g. $[11,13])$. Taking only inorganic species and their interactions into account such models could successfully simulate estimated residence times of trace metals in oceans or discuss some aspects of phosphate transport in lakes [12] thus supporting 'the hypothesis of the scavenging mineral particles' passing through the aquatic systems. 
In contrast to the above findings mass balances and mass transport studies of natural lakes could not give any indications that sorption or desorption of trace metals [1] or phosphate [8] on mineral surfaces would play an important role. According to their conclusions particles entering a completely aerobic lake remain relatively unchanged until they reach the sediment, serving neither as potent sinks nor potent sources while passing through the water column.

In recent years different studies of the adsorption characteristics of natural organic matter (e.g. [5]) and defined low molecular weight molecules [9] indicate that the presence of dissolved organic molecules might change the adsorption behaviour of mineral surfaces.

The present work aims to elucidate the apparent contradiction between the results of fundamental laboratory experiments and the phenomenology of mass transport studies of natural systems. Known experimental methods in adsorption studies are modified in order to match better the boundary conditions found in lakes.

\section{Methods and materials}

\subsection{Boundary conditions for adsorption studies}

Dissolved organic carbon (DOC) is chosen as a most simple sum parameter for natural organic matter (NOM). Previous studies in different Swiss lakes $[2,4]$ have shown that there are relatively small variations of DOC concentration as a function of time and depth. Oligotrophic systems show concentration ranges of $0.5-1 \mathrm{mg} / 1$, strongly eutrophic ones show ranges of 4-5 mg/l. For the present work samples of different depths and the inflow of Lake Alpnach were taken. DOC isopleths are shown in figure 1 (for more information see Krummenacher [8], Baccini [1].

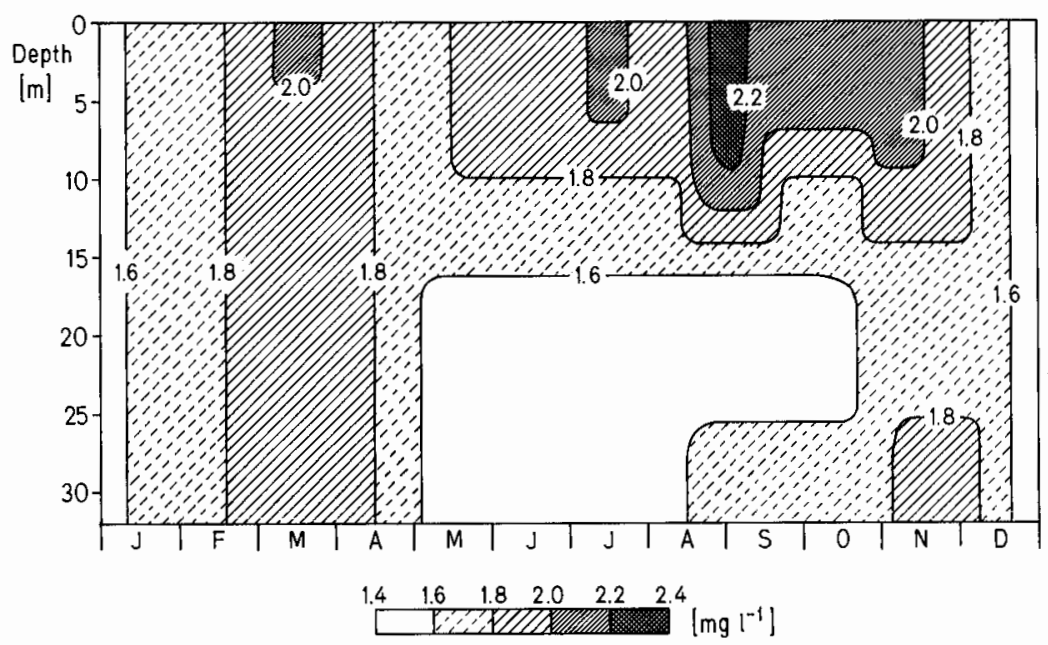

Figure 1. DOC isopleths of Lake Alpnach. 
Table 1. Boundary conditions for adsorption studies with mineral particles and organic matter.

\begin{tabular}{|c|c|c|c|c|c|c|c|}
\hline & $\begin{array}{l}\mathrm{DOC} \\
(\mathrm{mg} / \mathrm{l})\end{array}$ & $\begin{array}{l}\text { Mineral particles } \\
\text { (mg dry matter } / \text { l) }\end{array}$ & Type & $\begin{array}{l}\text { Electrolyte media } \\
\text { (M) }\end{array}$ & $\mathrm{pH}$ & $\begin{array}{l}\text { DOC }_{\text {ads. }} \\
\text { (\% of tot.) }\end{array}$ & Reference \\
\hline Swiss lakes & $1-5$ & $1-20$ & $\overline{\left.B^{1}\right)}$ & $\begin{array}{l}\mathrm{Ca}\left(\mathrm{HCO}_{3}\right)_{2} \\
1-2 \times 10^{-3}\end{array}$ & $7.5-9.0$ & & \\
\hline This work & 2 & $2-16$ & $\begin{array}{l}\gamma-\mathrm{Al}_{2} \mathrm{O}_{3} \\
\left.\mathrm{~B}^{1}\right)\end{array}$ & $\begin{array}{l}\mathrm{Ca}\left(\mathrm{HCO}_{3}\right)_{2} \text { or } \mathrm{Na} \mathrm{HCO}_{3} \\
10^{-3} \quad 2 \times 10^{-3}\end{array}$ & 8.0 & $\begin{array}{l}<20 \\
<10\end{array}$ & \\
\hline Recent & 10 & $200-10,000$ & $\gamma-\mathrm{Al}_{2} \mathrm{O}_{3}$ & & $4-9$ & 20 & Davis [5] \\
\hline Laboratory & $10-100$ & $2,000-20,000$ & $\gamma-\mathrm{Al}_{2} \mathrm{O}_{3}$ & $\mathrm{NaClO}_{4} \quad 0.1$ & $4-9$ & 20 & Kummert [10] \\
\hline Experiments & $1-50$ & 100 & $\mathrm{FeO}_{2} \mathrm{OH}$ & $\begin{array}{l}I=2 \times 10^{-3} \\
\text { (Esthwaite Water) }\end{array}$ & $\begin{array}{l}4-9 \\
(7.1)\end{array}$ & & Tipping [17] \\
\hline
\end{tabular}

1) Fraction of natural sediment, see table 2 and figure 3.

In the same lake concentration of particulate iron gives a good measure for the concentration of allochthonous mineral particles [1] namely $1-10 \mathrm{mg} / 1$ dry matter. The boundary conditions chosen are summarized in table 1 and compared with those found in prealpine Swiss lakes and in recent adsorption studies.

The main difference between earlier studies and this work is the drastic reduction of particle concentration down to a few $\mathrm{mg} / \mathrm{l}$. $\mathrm{pH}$ was kept at 8.0 because previous studies [5,9] have shown that in the relevant range from 7.5 to 9 only minor changes in adsorption of organic matter can be observed. Based on observations in natural systems the main variable is considered to be the particle concentration whereas the bulk of dissolved organic matter remains practically constant, i.e. only a few percent of the total OC is adsorbed on the particle surface.

\subsection{Determination of adsorbed organic matter on mineral particles}

The chosen method combination is presented schematically in figure 2 . From stock suspensions of approximately $30 \mathrm{~g} / 1$ in $2 \times 10^{-3} \mathrm{M} \mathrm{NaHCO}_{3}$ solutions $(\mathrm{pH}=8$ ) particles were transferred to volumes of 1 to 61 lake water or $\mathrm{NaHCO}_{3}$ solutions with DOC content between 1 and $4 \mathrm{mg} / 1$ giving suspensions of 64 to $1 \mathrm{mg} / \mathrm{l}$. The suspensions were shaken during $20 \mathrm{~h}$ at $20^{\circ} \mathrm{C}$ and then filtered through a glass filter (Whatman GF/C, diameter $5.5 \mathrm{~cm}$ ) which is covered by a layer of magnesium hydroxide carbonate $\left(\mathrm{Mg}_{4}\left(\mathrm{CO}_{3}\right)_{2}(\mathrm{OH})_{4}\right.$ from Merck). Solutions with corresponding volumes but without particles served as blanks. The $\mathrm{pH}$ was measured with a glass electrode before and after equilibration $(8.0 \pm 0.05)$.

The filters were folded twice and transferred into a 5-ml homogenizor (after Potter, $675 \mathrm{~S}$ from B. Braun). A milky and flocky suspension is produced which is transferred into a $10-\mathrm{ml}$ glass tube with $0.5 \mathrm{M} \mathrm{HCl}$. This suspension has a 100-600-fold higher concentration of particles than the corresponding original suspension. With a syringe $30 \mu \mathrm{l}$ of the concentrated suspension, homogenized in an ultrasound bath, are added to a platinum boat containing manganese dioxide. With Dohrmann's 'Total organic carbon analyzer' (DC, $50 / 52$ plus an automatic sample boat inlet) the 


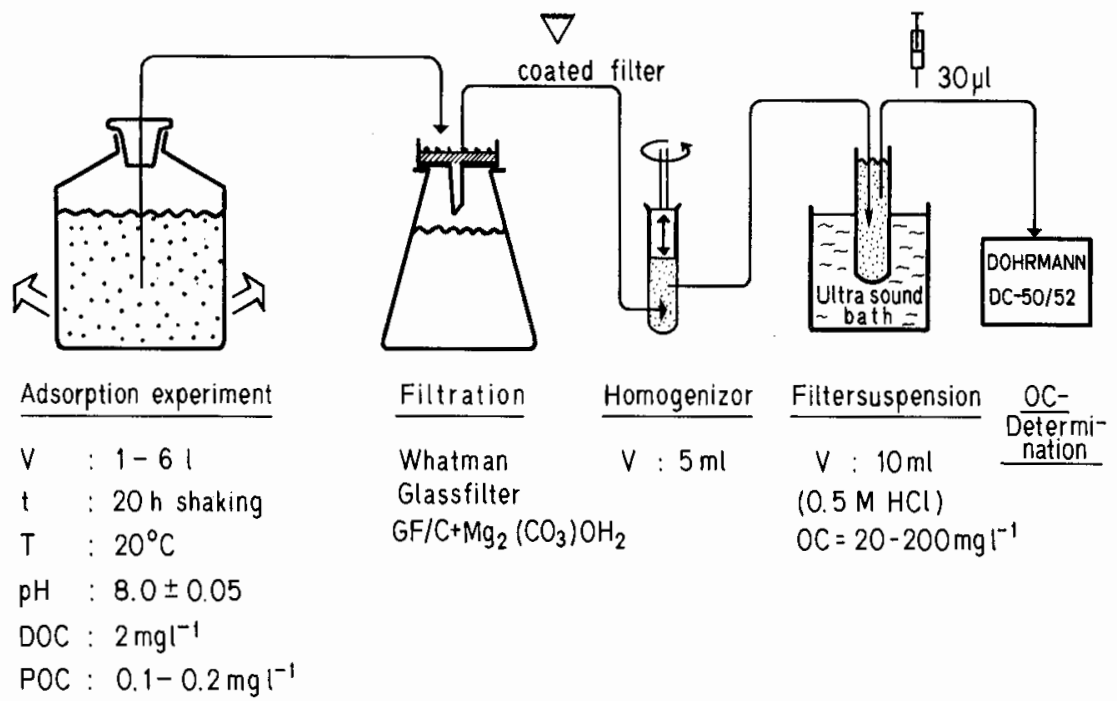

Figure 2. Scheme of method combination for determining adsorbed organic matter.

inorganic carbon is removed as $\mathrm{CO}_{2}$ in a first step. Afterwards the organic carbon is oxidized pyrolytically, reduced to $\mathrm{CH}_{4}$ and determined with a FID. The limit of detection of this method lies at $0.02 \mathrm{mg} / \mathrm{l}$ adsorbed organic carbon of the original solution $(\mathrm{V}=61)$.

\subsection{The choice and characterization of mineral particles}

$\gamma-\mathrm{Al}_{2} \mathrm{O}_{3}$ (aluminium oxide $\mathrm{C}$, Degussa, Frankfurt) served as reference particle. The pretreatment of the commercial product was made according to Kummert [9].

Natural particles were separated from the oxidized $3 \mathrm{~cm}$ top layer of a sediment core (taken from Lake Alpnach at a depth of $32 \mathrm{~m}$ on 29 January 1980). An Atterberg particle size fractionation gave $50 \%$ silt $(2 \mu \mathrm{m}<\mathrm{S}<63 \mu \mathrm{m})$ and $50 \%$ clay $(\mathrm{T}<2 \mu \mathrm{m})$. The bulk sediment $\mathrm{B}$ and the clay fraction $\mathrm{T}$ were lyophilized at $10^{-3}$ Torr during $24 \mathrm{~h}$ giving $\mathrm{B}_{1}$ and $\mathrm{T}_{1}$. Fractions of $\mathrm{B}, \mathrm{S}$ and $\mathrm{T}$ were also pyrolized at $550^{\circ} \mathrm{C}$ to remove the organic matter. The resulting particles were named $\mathrm{Bg}, \mathrm{Sg}, \mathrm{Tg}$.

BET measurements of the specific surface area were made after drying at $200{ }^{\circ} \mathrm{C}$ for $24 \mathrm{~h}$. The pyrolytic procedure and lyophilization changed the particle size distribution of B only slightly (fig. 3). This observation is in agreement with the measured surface areas given in table 2 . The surface areas of the silt and clay fractions ( $\mathrm{Sg}$ and $\mathrm{Tg}$ ), each $50 \%$ of $\mathrm{B}$, are in agreement with the surface found for the mixture Bg. A comparison of surface concentrations determined in separate adsorption experiments under analogous boundary conditions for $\mathrm{Sg}, \mathrm{Tg}$ and $\mathrm{Bg}$, shows that $\Gamma(\mathrm{Bg})$ is identical to the arithmetic mean of $\Gamma(\mathrm{Sg})$ and $\Gamma(\mathrm{Tg})$ (table 3). Such a finding indicates that the observed transfer of organic matter from the dissolved to the solid phase is an adsorption process, hardly influenced by other reactions such as flocculation or coprecipitations. In this work only $\gamma$-alox and $\mathrm{Bg}$ were chosen for adsorption studies. 


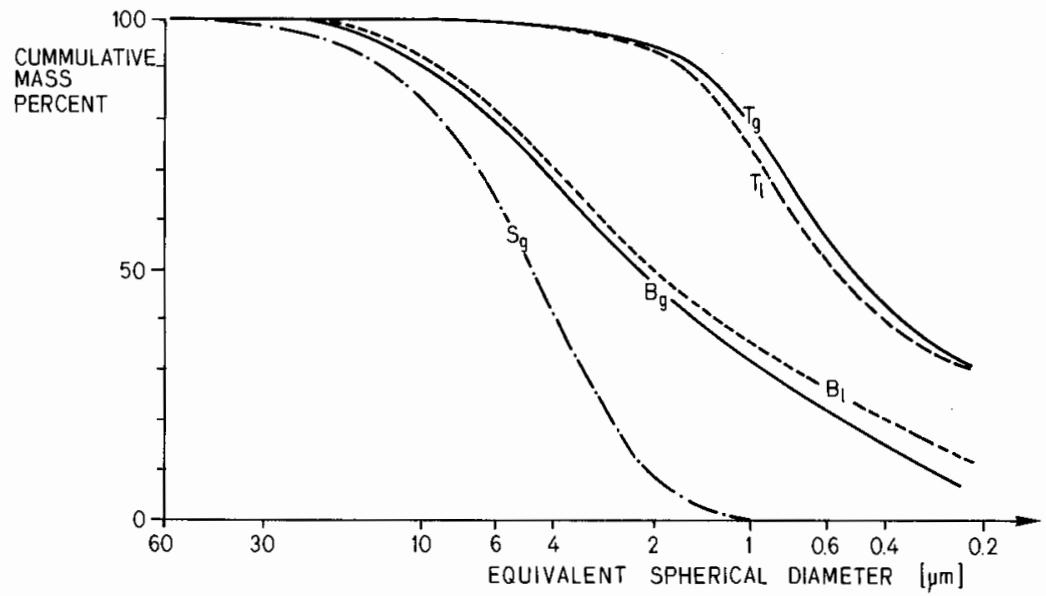

Figure 3. Particle size distribution of sediment fractions from Lake Alpnach.

Table 2. BET-surface areas and surface concentrations of organic carbon of chosen particles.

\begin{tabular}{lcc}
\hline Particle & $\begin{array}{l}\text { BET surface } \\
\left(\mathrm{m}^{2} \mathrm{~g}^{-1}\right)\end{array}$ & $\begin{array}{l}\text { Surface concentration } \\
\left(\mathrm{mg} \mathrm{OCg}^{2}\right)\end{array}$ \\
\hline $\mathrm{B}_{1}$ & 18 & 18.7 \\
$\mathrm{~B}_{\mathrm{g}}$ & 19 & 1.1 \\
$\mathrm{~S}_{\mathrm{g}}$ & 7 & 0.1 \\
$\mathrm{~T}_{\mathrm{g}}$ & 29 & 0.1 \\
$\left.\mathrm{~T}_{\mathrm{g}}+\mathrm{S}_{\mathrm{g}} / 2^{3}\right)$ & 18 & - \\
$\mathrm{T}_{1}$ & 29 & 24.8 \\
;-alox & 130 & 0.1 \\
\hline
\end{tabular}

1) Error: $\pm 1 \mathrm{~m}^{2} \mathrm{~g}^{-1}$.

2) Error: $\pm 0.2 \mathrm{mgg}^{-1}$

3) Assuming: Surface of $B_{g}=1 / 2$ surface $T_{g} \quad 1 / 2$ surface $S_{g}$.

Table 3. Comparison of surface concentration of different particle size fractions.

\begin{tabular}{lc}
\hline Particle & $\begin{array}{l}\text { Surface concentration } \\
\left(\mathrm{mg} \mathrm{OCg}^{-1}\right)\end{array}$ \\
\hline $\mathrm{S}_{\mathrm{g}}$ & $6.0 \pm 0.5$ \\
$\mathrm{~T}_{\mathrm{g}}$ & $17.0 \pm 0.2$ \\
$\mathrm{~B}_{\mathrm{g}}$ & $11.0 \pm 0.2$ \\
$\left.\left(\mathrm{~S}_{\mathrm{g}}+\mathrm{T}_{\mathrm{g}}\right) / 2^{1}\right)$ & $11.5 \pm 0.7$ \\
\hline
\end{tabular}

1) Calculated from $S_{g}$ and $T_{g}$.

Boundary conditions: Filtered lake water $(<0.45 \mu \mathrm{m})$ from Lake Alpnach (4 June 1980, depth $5 \mathrm{~m}$ ). $(\mathrm{DOC})=2.2 \mathrm{mg} / \mathrm{l}$. Particle concentration: $4 \mathrm{mg} / \mathrm{l}$. 


\subsection{The choice of natural organic matter (NOM)}

Filtered lake water (Millipore, $0.45 \mu \mathrm{m}$ ) was used as the starting material. For the adsorption studies two different procedures were chosen:

1. Adding particles in the desired quantity to the water ('lake water tel quel').

2. Adding particles and concentrated NOM, either as bulk organic matter or as molecular size fraction (procedure described by Baccini et al. [2]) in the desired quantities ot $\mathrm{NaHCO}_{3}\left(2 \times 10^{-3} \mathrm{M}\right)$.

The comparison of surface concentrations in table 4 indicates that neither the substitution of $\mathrm{Ca}^{2+}$ by $\mathrm{Na}^{+}$nor the concentration, fractionation and subsequent dilution of natural organic matter influence the overall adsorption pattern under the given boundary conditions.

Table 4. Comparison of surface concentrations using different procedures for selecting natural organic matter.

\begin{tabular}{lll}
\hline Sample, procedure & $\begin{array}{l}\text { DOC } \\
\left(\mathrm{mg} \mathrm{l}^{-1}\right)\end{array}$ & $\begin{array}{l}\text { Surface concentration } \\
\left(\mathrm{mg} \mathrm{OCg}^{-1}\right)\end{array}$ \\
\hline $\begin{array}{l}\text { Filtered 'lake water tel quel' } \\
\left(\mathrm{Ca}\left(\mathrm{HCO}_{3}\right)_{2}=10^{-3} \mathrm{M}\right)\end{array}$ & 1.4 & $27 \pm 1$ \\
$\begin{array}{l}\text { Lake water concentrate, diluted } \\
\text { in NaHCO}\end{array}$ & $2 \times 10^{-3} \mathrm{M}$ \\
$\begin{array}{l}\text { Sum of three gel fractions of lake } \\
\text { water concentrate, diluted in }\end{array}$ & 1.4 & $25 \pm 1$ \\
$\mathrm{NaHCO}_{3}=2 \times 10^{-3} \mathrm{M}$ & & \\
\hline
\end{tabular}

Boundary conditions: Particle: $\gamma-\mathrm{Al}_{2} \mathrm{O}_{3}$, particle concentration: $8 \mathrm{mg} \mathrm{l}^{-1}, \mathrm{pH}=8.0$, lake water sample: Lake Alpnach (24 April 1980, depth $5 \mathrm{~m}$ ).

\subsection{Determination of the adsorption of copper, zinc and phosphate}

The amount of adsorbed copper, zinc and phosphate was determined by the difference between the sample without particles (blank) and the dissolved phase of the sample with particles after centrifugation of $300 \mathrm{ml}$ at $5000 \mathrm{rpm}$ for $15 \mathrm{~min}$.

Metal analysis was performed by AAS [2]. The initial concentrations were: $\mathrm{Cu}_{\mathrm{i}}=5 \times 10^{-8} \mathrm{M}, \mathrm{Zn}_{\mathrm{i}}=10^{-7} \mathrm{M}$. Phosphate was determined spectrochemically with the molybdenum blue method [18]. The initial concentration was: $\mathrm{PO}_{4 \mathrm{i}}=2.4 \times 10^{-6} \mathrm{M}$.

\section{Results}

\subsection{The adsorption of NOM as a function of particle concentration}

For $\gamma$-alox the surface concentration as a function of the particle concentration can be described with $\Gamma=\mathrm{a}[\mathrm{P}]^{\mathrm{n}}$ within the range from 1 to $64 \mathrm{mg} / 1$, as shown in figure 4 . For Bg such a relation is only valid within a range which covers the one found in most prealpine lakes. At a given particle concentration, $\Gamma \mathrm{Bg}$ is smaller than $\Gamma_{\gamma \text {-Alox }}$. Varying the total DOC concentration within the range found in most lakes (see chapter 2.1) at a constant particle concentration results in surface concentrations that do not show significant differences (table 5). 


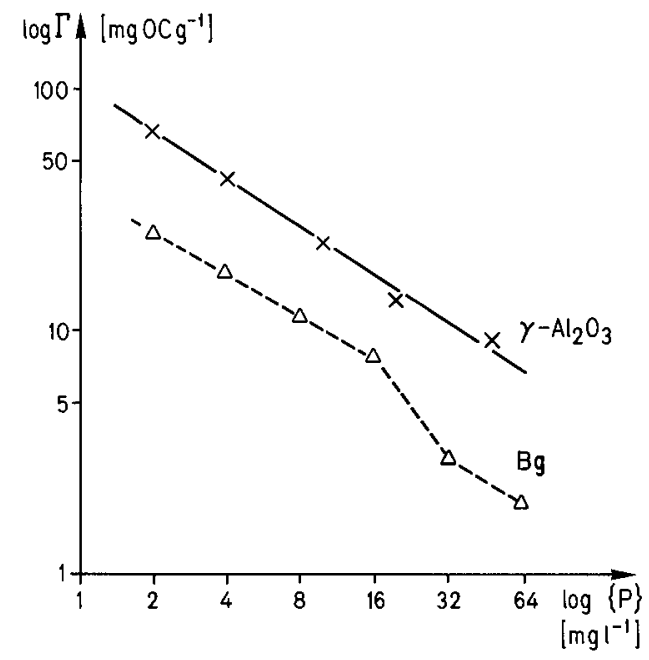

Figure 4. Surface concentration of organic matter as a function of particle concentration.

Table 5. Surface concentration as a function of DOC concentration.

\begin{tabular}{ll}
\hline $\begin{array}{l}\text { DOC } \\
\left(\mathrm{mg} \mathrm{l}^{-1}\right)\end{array}$ & $\begin{array}{l}\text { Surface concentration } \\
\left(\mathrm{mg} \mathrm{OCg}^{-1}\right)\end{array}$ \\
\hline 1 & $9.0 \pm 1.5$ \\
2 & $12.5 \pm 1.5$ \\
3 & $10.0 \pm 1.5$ \\
4 & $11.5 \pm 1.5$ \\
\hline
\end{tabular}

Particle: $\mathrm{Bg}$ particle concentration: $8 \mathrm{mg} \mathrm{1}^{-1}$.

Electrolyte: $2 \times 10^{-3} \mathrm{M} \mathrm{NaHCO}_{3}, \mathrm{pH}=8.0$.

DOC dosage from lake water concentrate (Lake Alpnach, 7 July 1980, depth $5 \mathrm{~m}$ ).

\subsection{The adsorption of NOM as a function of molecular size and origin of organic matter}

Water samples from different parts of the same lake, namely the inflow to Lake Alpnach (Grosse Schliere), the epilimnion (depth $5 \mathrm{~m}$ ) and the hypolimnion (depth $25 \mathrm{~m}$ ) showed different adsorption values (fig. 5). For both type of particles the sequence of increasing surface concentration $\Gamma$ is

hypolimnion $<$ epilimnion $<$ inflow.

The three samples differ in their molecular size distribution (fig.6). A comparison of the UV absorption and the DOC concentration (insert) of three size fractions (molecular size range I $\geqslant 1500>$ II $\geqslant 500 \geqslant$ III, after Gloor et al. [6]) shows clearly that the inflow has the largest portion of high molecular sizes and the hypolimnion the largest portion of low molecular sizes. Adsorption experiments with the individual fractions I, II and III give the following results (table 6): 

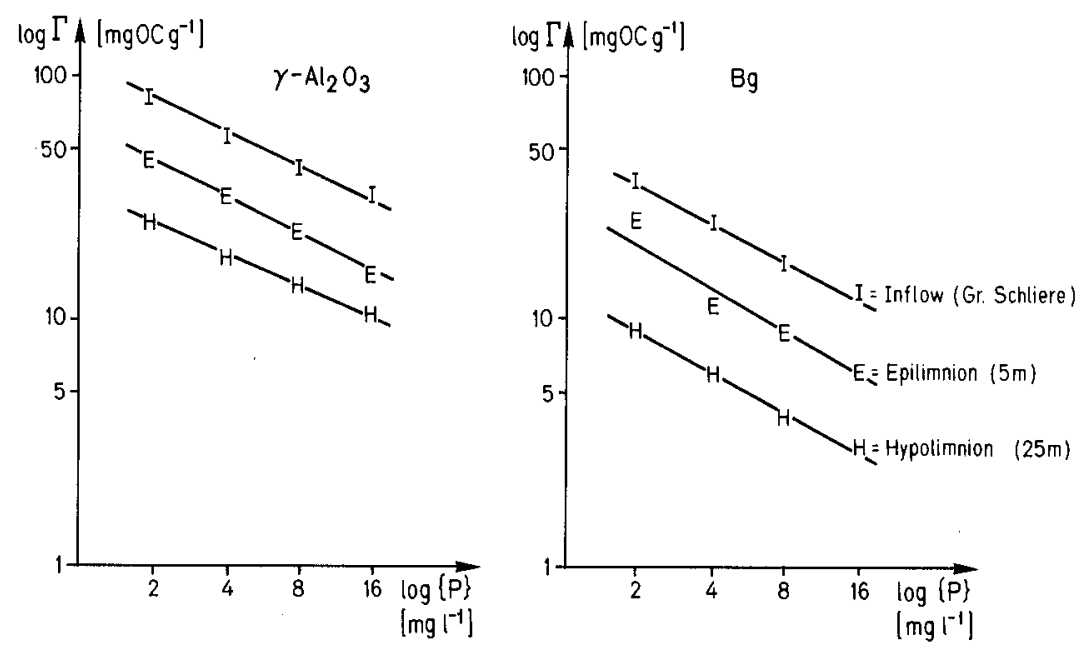

Figure 5. Comparison of adsorption of organic matter from different origins (Lake Alpnach).

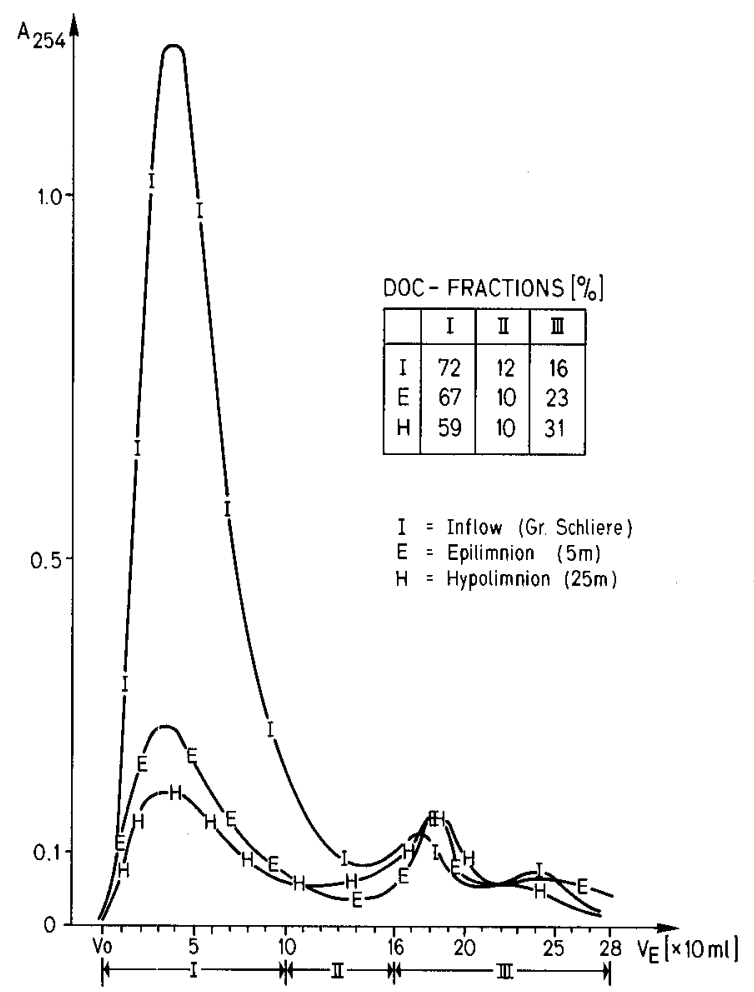

Figure 6. Molecular size fractionation of natural organic matter from inflow and lake water (Lake Alpnach). 
1. The greater the molecular size the greater the surface concentration of organic carbon. This phenomenon is well known for clayorganic matter interaction [14].

2. A mixture of the three fractions, taking the proportions given in table 6 , gives a surface concentration equivalent to a calculated one (see footnote in table 6).

The phenomenology presented in figure 5 can be explained at least qualitatively by the differences in molecular size distribution of NOM.

Table 6. Surface concentration as a function of molecular size.

\begin{tabular}{lll}
\hline Molecular size fraction & \\
& & $\begin{array}{l}\left.\text { Surface concentration } \Gamma^{2}\right) \\
\left(\mathrm{mg} \mathrm{OC} \mathrm{g}^{-1}\right)\end{array}$ \\
\hline I & DOC portion $\left.^{3}\right)(\%)$ & 36 \\
II & 53 & 26 \\
III & 12 & 13 \\
Mixture $\left.^{4}\right)$ & 35 & 28 measured \\
& & 27 calculated $\left.^{5}\right)$ \\
\hline
\end{tabular}

\footnotetext{
1) Refer to figure 6.

2) Boundary conditions: $\gamma$-alox: $8 \mathrm{mg} \mathrm{l}^{-1}$; (DOC): $1.5 \mathrm{mg} \mathrm{l}^{-1}$; electrolyte: $2 \times 10^{-3} \mathrm{M} \mathrm{NaHCO}_{3}, \mathrm{pH}=8.0$.

3) Lake water concentrate (Lake Alpnach, 24 March 1980, depth $5 \mathrm{~m}$ ) fractionated on sephadex G-25.

4) Mixture made from I, II, III considering original DOC portions.

5) Mixture $=1 / 100\left(\mathrm{X}_{\mathrm{I}} \Gamma_{\mathrm{I}}+\mathrm{X}_{\mathrm{II}} \Gamma_{\mathrm{II}}+\mathrm{X}_{\mathrm{III}} \Gamma_{\mathrm{III}}\right)$, where $\mathrm{X}_{\mathrm{i}}=$ proportion of DOC in $\%$.
}

\subsection{The influence of NOM on copper, zinc and phosphate adsorption}

Organic matter influences strongly the adsorption of the cations $\mathrm{Cu}^{2+}$ and $\mathrm{Zn}^{2+}$ and the anion o- $\mathrm{PO}_{4}$ (fig. 7). In the presence of NOM all three ions are less adsorbed on $\gamma$-alox.

The same phenomenology is observable for the particles $\mathrm{Bg}$ with copper and zinc. Since $\mathrm{Bg}$ is also a strong source of $\mathrm{o}-\mathrm{PO}_{4}$ ions an analogous experiment is not possible for these ions.

\section{Discussion}

\subsection{Significance of surface concentration of NOM}

According to Kummert and Stumm [10] $\gamma$-alox has a maximum adsorption density of approximately 1 molecule per $\mathrm{nm}^{2}$ for an organic acid such as salicylic acid. This surface concentration corresponds well to the experimentally determined concentration of OH-groups on the $\gamma$-alox surface. The same authors conclude that with simple aromatic acids it is possible to form a closed packed monolayer of molecules with their acid groups facing the surface. For salicylic acid the number of organic Catoms per binding site would therefore be 7 .

The corresponding surface concentrations of NOM expressed in C-atoms per $\mathrm{nm}^{2}$ are given in figure 8 . The data is taken from figure 4 ( $\Gamma$-values) and table 2 (specific surface). Although no detailed information about the chemical composition and 


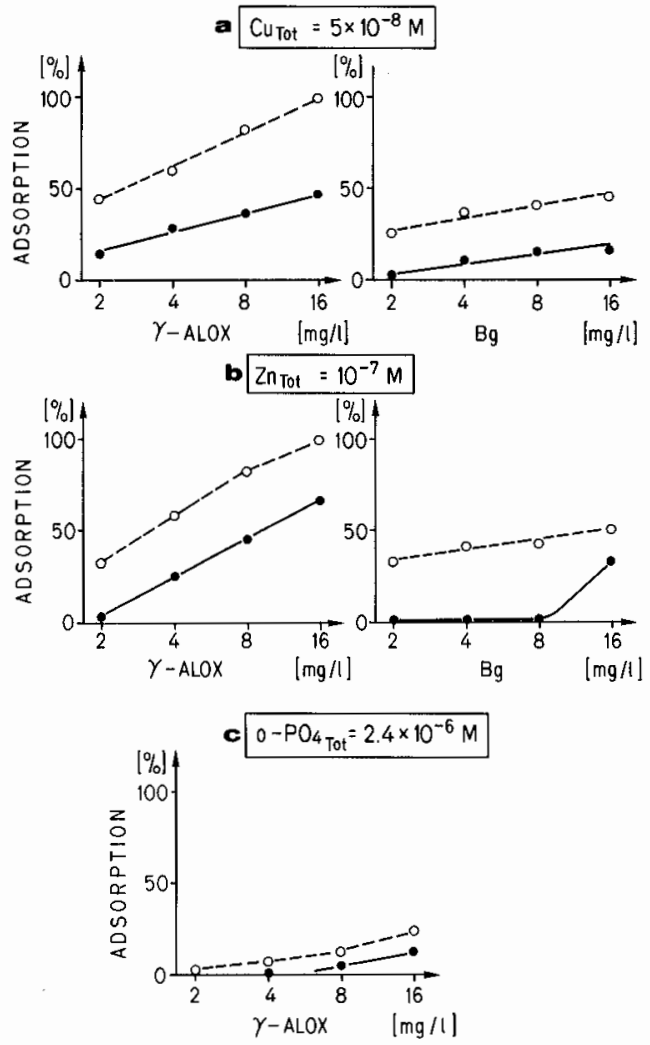

Figure 7. Copper, zinc and phosphate adsorption as a function of NOM and particle concentration. $\mathrm{NaHCO}_{3}: 2 \times 10^{-3} \mathrm{M}, \mathrm{pH}=8$. O---O : without NOM, --- with NOM (2 mg DOC/1).

structure of NOM is available several independent studies (e.g. $[4,5,15,2])$ give compatible main characteristics which can be summarized as follows:

- The bulk of dissolved NOM $(80 \%)$ in most investigated surface waters is of the fulvic acid type with molecular weights in the range of 500 to 2000 daltons.

- The functional groups present are predominantly carboxylic, hydroxyl and phenolic hydroxyl. The percentage of aromatic C-atoms is at least $25 \%$.

- The adsorption behaviour of NOM from filtrated lake water corresponds well to the characteristics observed with salicylic or phtalic acid [5].

Assuming one benzene ring per 24 organic $\mathrm{C}$-atoms and for each ring one carboxylic and phenolic group (based on data by Thurman [16]) one aromatic acid group bound to a surface site would result in $24 \mathrm{C}$-atoms per $\mathrm{nm}^{2}$ for $\gamma$-alox. At a concentration of $2 \mathrm{mg} / 1 \gamma$-alox the surface could be covered completely by NOM (fig. 8 ).

With a molecular weight of approximately 1000 daltons two functional groups per molecule would be bound to the surface (assuming that NOM is 50\% carbon by weight). Larger molecules with several functional groups bound to surface sites should be thermodynamically more favorable than small molecules with only one 
binding site (table 6). It cannot be excluded that the phenomena shown in figure 5 are not only due to different molecular size fractions but also a result of chemical differences between NOM from the inflow (I) and NOM from the lake (E and H). The different ratios $\mathrm{A}_{254} / \mathrm{DOC}$ (fig. 6) support such a possibility [4]. The binding site concentration of $\mathrm{Bg}$ surfaces cannot be determined adequately (perturbation by reactive iron species at higher $\mathrm{pH}$ values). From data in figure 8 one can conclude that the adsorption density on Bg is 3-4 times higher than on $\gamma$-alox. Such a density would correspond to 3-4 binding sites per $\mathrm{nm}^{2}$, a value which is observed for goethite [12]. For stereochemical reasons however it is more likely that benzoic groups have a maximum adsorption of 1 molecule per $\mathrm{nm}^{2}$ [9]. Therefore the higher surface concentration of $\mathrm{Bg}$ could be due to the formation of several NOM layers. Under natural conditions the mineral particles in suspension are exposed to NOM having higher molecular weights with even stronger adsorption properties. This fraction is excluded by the chosen separation technique $(<0.45 \mu \mathrm{m})$.

Within the range of experimental concentrations no saturation was observed (a phenomenon detected by Davis [5], for a small specific fraction of sediment pore water). Therefore one could postulate that under the chosen boundary conditions the binding sites of $\mathrm{Bg}$ are saturated with NOM at a concentration of approximately $\leqslant 8 \mathrm{mg} / \mathrm{l}$ (fig. 8 ).

The significance of such a hypothesis can be summarized as follows:

1. In lake water mineral particles in concentrations of a few $\mathrm{mg} / \mathrm{l}$ have surfaces covered dominantly by NOM (fig. 8).

2. NOM can compete successfully with cations and anions (fig. 7) for surface binding sites of the type ( $\equiv \mathrm{S}-\mathrm{OH})$.

3. Due to the competition between NOM and inorganic ions, sedimenting mineral particles in small concentrations would be poor scavengers either for heavy metals or for o-phosphate.

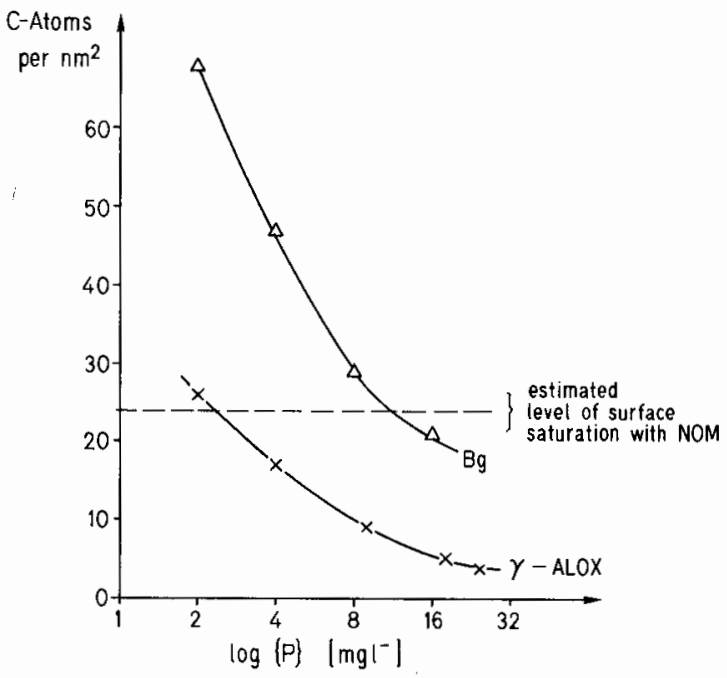

Figure 8. Calculated number of $\mathrm{C}$-atoms per $\mathrm{nm}^{2}$ as a function of particle concentration. 
The third postulate is certainly not valid for newly formed particles such as iron(III) oxides (at the hypolimnic $\mathrm{Fe}^{3+} / \mathrm{Fe}^{2+}$ interface) which are good scavengers, e.g. for phosphate [13] and copper [3].

\subsection{An adsorption model for mineral particles in lake water considering NOM}

A simple and efficient model describing adsorption of ionic species on charged surfaces has been elaborated by Westall [20].

The programs MICROQL I and II [19] were used:

a) To fit experimental data of NOM adsorption (fig.4) with equilibrium constants for the reaction

$$
\mathrm{SOH}+\mathrm{H}_{2} \mathrm{X} \rightleftharpoons \mathrm{SX}^{-}+\mathrm{H}_{3} \mathrm{O}^{+}
$$

in which $\mathrm{H}_{2} \mathrm{X}$ stands for NOM. The corresponding acidity constants are taken from salicylic acid. This approximation is based on the observation made by Kummert [9] that NOM from lake water is showing very similar characteristics as salicylic acid with respect to adsorption on $\gamma$-alox. The total concentration of $\mathrm{H}_{2} \mathrm{X}$ was estimated by assuming an average molecular weight of 1000 daltons, in which one out of two aromatic rings has a salicylic group and carbon is $50 \%$ by weight. (Details of the matrix are given in appendix I.)

b) To fit experimental data on copper, zinc and o-phosphate adsorption in a purely inorganic medium (fig. 7) with equilibrium constants for the reactions.

$$
\begin{aligned}
& \mathrm{SOH}+\mathrm{M}^{+2} \rightleftharpoons \mathrm{SOM}^{+}+\mathrm{H}^{+} \\
& \mathrm{SOH}+\mathrm{H}_{3} \mathrm{PO}_{4} \rightleftharpoons \mathrm{SH}_{2} \mathrm{PO}_{4}+\mathrm{H}_{2} \mathrm{O} \\
& \mathrm{SOH}+\mathrm{H}_{3} \mathrm{PO}_{4} \rightleftharpoons \mathrm{SH} \mathrm{PO}_{4}+\mathrm{H}_{3} \mathrm{O}^{+} \\
& \mathrm{SOH}+\mathrm{H}_{3} \mathrm{PO}_{4} \rightleftharpoons \mathrm{SPO}_{4}{ }^{2-}+\mathrm{H}_{3} \mathrm{O}^{+}+\mathrm{H}^{+}
\end{aligned}
$$

c) To calculate species distribution for the systems $\left(\gamma\right.$-alox, NOM, $\left.\mathrm{Cu}^{2+}, \mathrm{Zn}^{2+}\right),(\mathrm{Bg}$, $\mathrm{NOM}, \mathrm{Cu}^{2+}, \mathrm{Zn}^{2+}$ ) and ( $\gamma$-alox, $\mathrm{NOM}, \mathrm{o}-\mathrm{PO}_{4}$ ) (see appendix II).

Based on the phenomenology of copper and zinc speciation in lake water described elsewhere [3], the following reactions were postulated:

Zinc does not form stable complexes with NOM under the chosen experimental conditions. Therefore only the reaction (2) is considered. However one cannot exclude the possibility that a more stable complex of NOM with zinc is formed on the surface.

Copper, contrary to zinc, forms stable complexes with NOM in solution:

$$
\mathrm{Cu}^{2+}+\mathrm{H}_{2} \mathrm{X} \rightleftharpoons \mathrm{CuX}+2 \mathrm{H}^{+} \text {. }
$$

The conditional constant for this reaction $(\mathrm{pH}=8)$ has already been determined [2]. Since the phenomenology indicates (fig. 7) that the presence of NOM does not enhance the sorption of copper a ternary complex of the $\equiv \mathrm{S}-\mathrm{O}-\mathrm{Cu}-\mathrm{X}$ type was not taken into account. However it is assumed that copper containing NOM has still free benzoic groups to be bound to the surface. Therefore the reaction

$$
\mathrm{S}-\mathrm{OH}+\mathrm{Cu}^{2+}+\mathrm{H}_{2} \mathrm{X} \rightleftharpoons \mathrm{S}-\mathrm{X}-\mathrm{Cu}^{+}+\mathrm{H}_{3} \mathrm{O}^{+}
$$

is postulated. It is assumed that the presence of $\mathrm{Cu}^{2+}$ in the molecule $\mathrm{X}$ does not influence the $\mathrm{S}-\mathrm{X}$ bond because of the relatively long intramolecular distance of the two sites (see chapter 4.1). It is assumed that the standard free energy of reaction (5) is equal to that for reaction (1). In other words $\mathrm{S}-\mathrm{X}-\mathrm{Cu}$ is not favored relative to $\mathrm{S}-\mathrm{X}$. 
For all calculations the 'constant capacitance model' was applied. In summary the applied model treats NOM as a medium sized molecule (molecular weight $\approx 1000$ ) $\approx 1000$ ) with a least one functional group of the salicylic type to be bound to the surface and at least one site where copper can be complexed to. The surface has also uniform binding sites of the S-O-H type undergoing substitution reactions at the 'quasi central atom' $\mathrm{S}\left(\mathrm{H}_{2} \mathrm{X}\right.$ and o- $\left.\mathrm{PO}_{4}\right)$ or at the oxygen $\left(\mathrm{Cu}^{2+}\right.$ and $\left.\mathrm{Zn}^{2+}\right)$.

The results of the model calculations are presented in figure $9, a-c$, and compared with measured values. The model cannot simulate the measured values in all cases but reflects quite well the influence of NOM on the adsorption characteristics (fig. 7). In particular the differences in adsorption behaviour of copper and zinc can be explained by different speciation due to NOM.
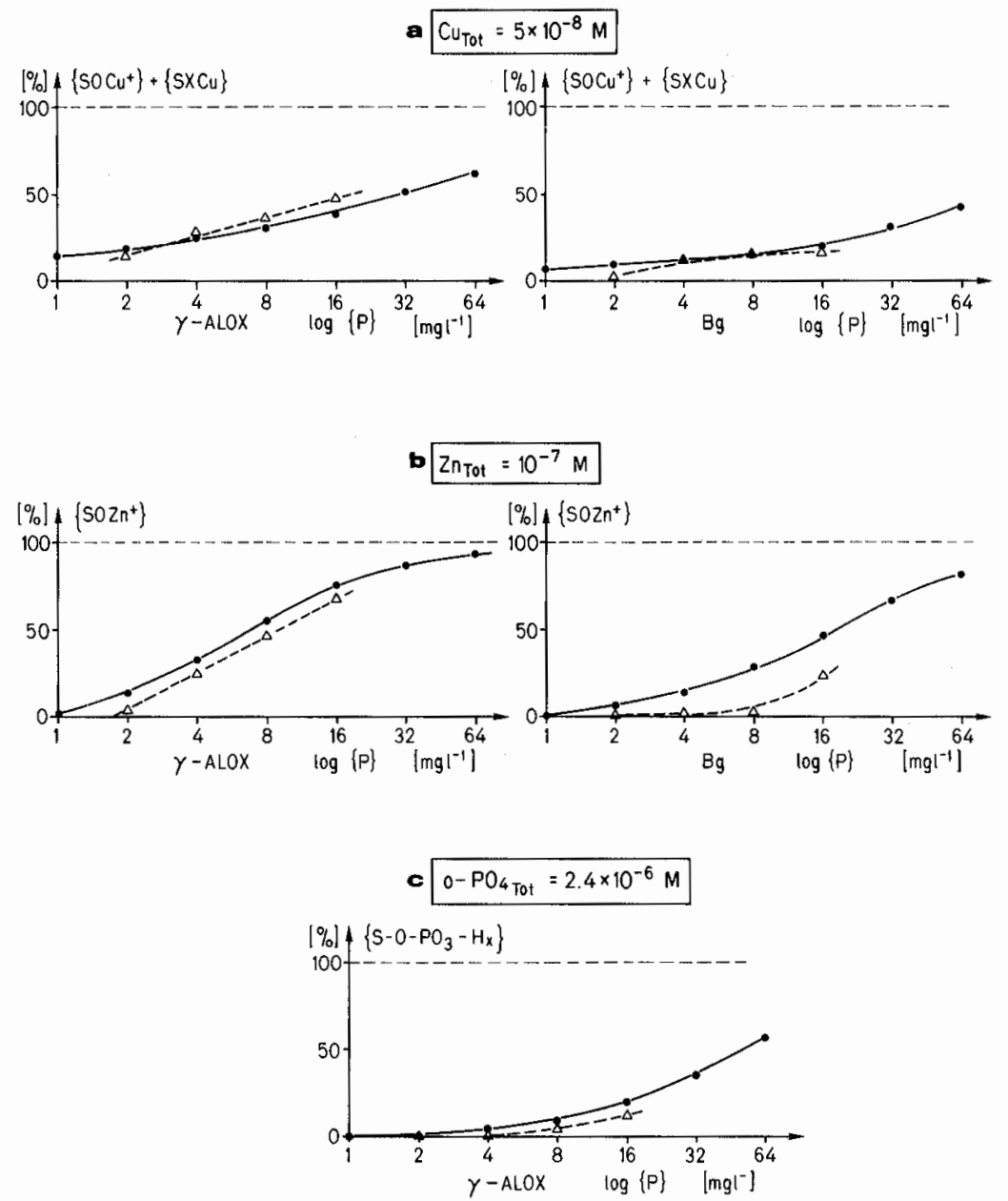

Figure 9. Comparison of model calculations $(-\bullet)$ with measured values $(\Delta-\cdots \Delta)$. 


\section{Summary}

The adsorption characteristics of a well-defined mineral particle ( $\gamma$-Alox) and a natural particle ( $\mathrm{Bg}$, isolated from the sediment surface of Lake Alpnach) were studied unter lake water conditions. A method was developped to measure adsorbed organic matter as organic carbon on mineral particles, which were suspended at low concentrations in filtered lake water or in an electrolyte solution of $2 \times 10^{-3} \mathrm{M}$ $\mathrm{NaHCO}_{3}$. At $\mathrm{pH}=8$ and particle concentrations between 2 and $16 \mathrm{mg} / 1$ natural organic matter (NOM) in the system reduced significantly the adsorption of the ions $\mathrm{Cu}^{2+}, \mathrm{Zn}^{2+}$ and $\mathrm{o}-\mathrm{PO}_{4} \mathrm{H}_{\times}$(fig. 7). Model calculations support the hypothesis that NOM can saturate the binding sites of the mineral surface at low particle concentrations ( $\leqslant 2 \mathrm{mg} / 1 \gamma$-alox, $\leqslant 8 \mathrm{mg} / 1 \mathrm{Bg}$ ) preventing other ions from being adsorbed (fig.9). The observed differences between copper and zinc adsorption can be explained by the differences in speciation due to NOM. The results of the experiments can also explain the findings that in prealpine lakes allochthonous particles are not very efficient scavengers while passing through the lacustrine water column.

\section{ZUSAMMENFASSUNG}

Der Einfluss natürlicher organischer Stoffe auf die Adsorptionseigenschaften mineralischer Partikeln in Seewasser

Unter Seewasserbedingungen wurde die Adsorptionscharakteristik einer Modellpartikel ( $\gamma$-Alox) und eines natürlichen Teilchens ( $\mathrm{Bg}$ aus der Grenzschicht des Alpnacherseesedimentes) untersucht. Zur Bestimmung des adsorbierten organischen Kohlenstoffs auf Partikeln in sehr niederen Konzentrationen (2-16 mg/l) in Seewasser oder im Elektrolyt $2 \times 10^{-3} \mathrm{M} \mathrm{NaHCO}_{3}$ wurde eine spezielle Methode entwickelt. Bei $\mathrm{pH}=8$ bewirken die natürlichen organischen Stoffe (NOM) eine signifikante Reduktion der Adsorption von $\mathrm{Cu}^{2+}, \mathrm{Zn}^{2+}$ und o- $\mathrm{PO}_{4} \mathrm{H}_{\times}$(Fig. 7). Modellberechnungen unterstützen die Hypothese, dass NOM bei niedrigen Partikelkonzentrationen ( $\leq 2 \mathrm{mg} / \mathrm{l}$ für $\gamma$-Alox und $\leq 8 \mathrm{mg} / \mathrm{l} \mathrm{Bg}$ ) den grössten Teil der Bindungsstellen auf der Oberfläche besetzen kann, so dass andere Ionen weniger oder nicht adsorbiert werden (Fig.9). Die beobachteten Unterschiede in der Kupfer- und Zinkadsorption können mit durch NOM bedingten Speziierungsunterschieden erklärt werden. Die experimentellen Befunde machen auch verständlich, warum allochthone mineralische Partikeln in voralpinen Seen nur eine unbedeutende «Scavenger-Rolle» ausüben.

\section{RÉSUMÉ}

L'influence des substances organiques et naturelles sur les propriétés d'adsorption des particules minérales dans les eaux lacustres

La caractéristique d'adsorption des particules minérales bien définies ( $\gamma$-alox) et des particules naturelles (Bg, isolée de la surface d'un sédiment du lac d'Alpnach) a été étudiée sous conditions lacustres. Pour mesurer le carbone organique adsorbé, à partir des concentrations très faibles des particules suspendues dans les eaux lacustres ou dans l'électrolyte $2 \times 10^{-3} \mathrm{M} \mathrm{NaHCO}_{3}$, une méthode a été développée. A $\mathrm{pH}=8$ et à une concentration des particules entre 2 et $16 \mathrm{mg} / 1$ la matière organique naturelle réduit significativement l'adsorption des ions $\mathrm{Cu}^{2+}, \mathrm{Zn}^{2+}$ et o- $\mathrm{PO}_{4} \mathrm{H}_{\times}$(fig.7). Des calculs modéles supportent l'hypothèse que NOM peut saturer les sites de laiaison des particules minérales ayant une concentration faible ( $\leqslant 2 \mathrm{mg} / 1 \gamma$-alox, $\leqslant 8 \mathrm{mg} / 1 \mathrm{Bg}$ ). Il en résulte une forte réduction d'adsorption pour les autres ions dans le système (fig.9). La différence dans l'adsorption entre le cuivre et le zinc peut être expliquée par une différence de spéciation due à NOM. Les résultats expérimentaux peuvent aussi expliquer l'observation faite dans les lacs préalpins que les particules minérales et allochtones ne sont pas des «scavengers» efficaces. 


\section{ACKNOWLEDGMENTS}

The authors wish to thank Dres. Jacques Buffle, René Schwarzenbach, Garrison Sposito and Mike Thurman for their constructive comments. We thank Heidi Bolliger for drawing the figures, Rita Bucher and Susy Graf for typing the manuscript.

\section{REFERENCES}

1 Baccini, P.: Untersuchungen über den Schwermetallhaushalt in Seen. Schweiz. Z. Hydrol. 38, 121158 (1976).

2 Baccini, P., and Suter, U.: Chemical speciation and biological availability of copper in lake water. Schweiz. Z. Hydrol. 41 (2), 291-314 (1979).

3 Baccini, P., and Joller, Th.: Transport processes of copper and zinc in a highly eutrophic and meromictic lake. Schweiz. Z. Hydrol. 43, 176-199 (1981).

4 Buffle, J., and Deladoey, P.: Analysis and characterization of natural organic matters in freshwaters. Part II: Comparison of the properties of waters of various origins and their annual trend. Schweiz. Z. Hydrol. (1982, submitted).

5 Davis, J.A.: Adsorption of natural organic matter from freshwater environments by aluminium oxide. In: Baker, R. A. (ed.): Contaminants and Sediments, vol. 2. Ann Arbor, MI (1980).

6 Gloor, R., Leidner, H., Wuhrmann, K., and Fleischmann, Th.: Exclusion chromatography with carbon detection. A tool for further characterization of dissolved organic carbon. Water Res. 15, 457-462 (1981).

7 Hohl, H., and Stumm, W.: Interaction of $\mathrm{Pb}^{2+}$ with hydrous $\gamma-\mathrm{Al}_{2} \mathrm{O}_{3}$. J. Colloid Interface Sci. 55 (2), 281-288 (1976).

8 Krummenacher, T.: Die Nährstoffbilanz des Alpnachersees. Diss. ETH, Nr.5689 (1976).

9 Kummert, R.: Die Oberflächenkomplexbildung von organischen Säuren mit $\gamma$-Alox und ihre Bedeutung für natürliche Gewässer. Diss. ETH, Nr.6371 (1979).

10 Kummert, R., and Stumm, W.: The surface complexation of organic acids on hydrous $\gamma-\mathrm{Al}_{2} \mathrm{O}_{3} . \mathrm{J}$. Colloid Interface Sci. 75 (2), 373-385 (1980).

11 Schindler, P.W.: The regulations of trace metal concentrations in natural water systems: a chemical approach. J. Great Lakes Res. 2, suppl. 1 (1976).

12 Sigg, L., and Stumm, W.: The interaction of anions and weak acids with the hydrous goethite ( $\alpha$ $\mathrm{FeOOH}$ ) surface. Colloids and Surfaces 2, 101-117 (1980).

13 Stumm, W., and Morgan, J.: Aquatic Chemistry, 2nd ed. John Wiley, N.Y. (1981).

14 Theng, B. K. G.: The chemistry of clay-organic reactions Wiley, N.Y. (1974).

15 Thurman, E.M., Wershaw, R.L., Malcolm, R.L., and Pinckney, D.J.: Molecular size of aquatic humic substances. Accepted for Organic Geochemistry (1982a).

16 Thurman, E. M.: Personal communication (1982b).

17 Tipping, E.: The adsorption of aquatic humic substances by iron oxides. Geochim. cosmochim. Acta 45, 191-199 (1981).

18 Vogler, P.: Beiträge zur Phosphatanalytik in der Limnologie. II. Die Bestimmung des gelösten Orthophosphates. Fortschr. Wasserchem. Grenzgeb. 2, 109-119 (1965).

19 Westall, J.: MICROQL. I. A Chemical equilibrium program in BASIC. II. Computation of adsorption equilibria in BASIC. Swiss Federal Institute of Technology, CH-8600 Dübendorf (1979).

20 Westall, J.: Chemical equilibrium including adsorption on charged surfaces. In: Kavanaugh, M.C., and Leckie, J.O. (eds): Advances in Chemistry Series, No.189, ACS (1980).

Address of the authors: Lake Research Laboratory, EAWAG/ETH, CH-6047 Kastanienbaum, Switzerland. 


\section{Appendix I}

a) Matrix for MICROQL I and II [19] used to fit the equilibrium constant of species $\mathrm{SX}^{-}$(data fig. 4).

\begin{tabular}{llrlrc}
\hline $\begin{array}{l}\text { Components } \\
\text { Species }\end{array}$ & $\mathrm{SOH}$ & $\mathrm{e}^{-} \frac{\mathrm{F} \psi}{\mathrm{RT}}$ & $\mathrm{H}_{2} \mathrm{X}$ & $\mathrm{H}^{+}$ & $\operatorname{log~K}$ \\
\hline $\mathrm{H}_{2} \mathrm{X}$ & 0 & 0 & 1 & 0 & 0 \\
$\mathrm{HX}^{-}$ & 0 & 0 & 1 & -1 & $\left.-2.8^{1}\right)$ \\
$\mathrm{X}^{2-}$ & 0 & 0 & 1 & -2 & $\left.-16.2^{1}\right)$ \\
$\mathrm{SOH}^{-}$ & 1 & 0 & 0 & 0 & 0 \\
$\mathrm{SOH}_{2}^{+}$ & 1 & 1 & 0 & 1 & $\left.7.2^{2}\right)$ \\
$\mathrm{SO}^{-}$ & 1 & -1 & 0 & -1 & $\left.-9.5^{2}\right)$ \\
$\mathrm{SX}^{-}$ & 1 & 0 & 1 & -1 & to be fitted \\
$\mathrm{H}^{+}$ & 0 & 0 & 0 & 1 & 0 \\
$\mathrm{OH}^{-}$ & 0 & 0 & 0 & -1 & -14 \\
\hline
\end{tabular}

1) $\mathrm{K}_{\mathrm{a}}$-values of salicylic acid.

2) After Hohl and Stumm [7].

$\gamma$-alox: specific surface area: $130 \mathrm{~m}^{2} \mathrm{~g}^{-1}$ (BET); surface concentration of binding sites: $2.1 \times 10^{-4}$ mole $\mathrm{g}^{-1}$; capacitance: 1.8 .

$\mathrm{Bg}$; specific surface area: $19 \mathrm{~m}^{2}$ (BET); surface concentration of binding sites: $9 \times 10^{-5}$ mole $\mathrm{g}^{-1}$; capacitance: 1.8

Boundary conditions: Ionic strength: $0.002 ; \mathrm{H}_{2} \mathrm{X}_{10 \mathrm{t}}=4 \times 10^{-6} \mathrm{M} ; \mathrm{pH}=8$.

Comments on $\mathrm{SX}^{-}$: It is assumed that the large molecule $\mathrm{X}$ is bound to the surface forming a chelate ring with a salicylic group at $\mathrm{pH}=8[10]$. Therefore the binding site stays electrically neutral.

However the capacity will be increased due to the 'polyelectrolyte' $\mathrm{X}$ with counterions $\left(\mathrm{Ca}^{2+}, \mathrm{Na}^{+}\right)$.

b) Matrix for MICROQL I and II used to fit the equilibrium constant of species S-O-M+ $(M=C u, Z n)$ (data fig. 7).

\begin{tabular}{llcccc}
\hline $\begin{array}{l}\text { Components } \\
\text { Species }\end{array}$ & $\mathrm{SOH}$ & $\mathrm{e}^{-\frac{\mathrm{F} \psi}{\mathrm{RT}}}$ & $\mathrm{M}^{2+}$ & $\mathrm{H}^{+}$ & $\log \mathrm{K}$ \\
\hline $\mathrm{M}^{2+}$ & 0 & 0 & 1 & 0 & 0 \\
$\mathrm{SOM}^{+}$ & 1 & 1 & 1 & -1 & to be fitted \\
$\mathrm{SOH}$ & 1 & 0 & 0 & 0 & 0 \\
$\mathrm{SOH}_{2}^{+}$ & 1 & 1 & 0 & 1 & 7.2 \\
$\mathrm{SO}^{-}$ & 1 & -1 & 0 & -1 & -9.5 \\
$\mathrm{H}^{+}$ & 0 & 0 & 0 & 1 & 0 \\
$\mathrm{OH}^{-}$ & 0 & 0 & 0 & -1 & -14 \\
\hline
\end{tabular}

Boundary conditions analogous to matrix a. 
c) Matrix MICROQL I and II used to fit the equilibrium constant of species $\mathrm{S}-\mathrm{O}-\mathrm{PO}_{3} \mathrm{H}_{\mathrm{X}}(\mathrm{x}=\mathrm{O}-2)$.

\begin{tabular}{llclcc}
\hline $\begin{array}{l}\text { Components } \\
\text { Species }\end{array}$ & $\mathrm{SOH}$ & $\mathrm{e}^{-\frac{\mathrm{F} \psi}{\mathrm{RT}}}$ & $\mathrm{H}_{3} \mathrm{PO}_{4}$ & $\mathrm{H}^{+}$ & $\log \mathrm{K}$ \\
\hline $\mathrm{H}_{3} \mathrm{PO}_{4}$ & 0 & 0 & 1 & 0 & 0 \\
$\mathrm{H}_{2} \mathrm{PO}_{4}^{-}$ & 0 & 0 & 1 & -1 & -2.1 \\
$\mathrm{HPO}_{4}^{2-}$ & 0 & 0 & 1 & -2 & -9.2 \\
$\mathrm{PO}_{4}^{3-}$ & 0 & 0 & 1 & -3 & -21.6 \\
$\mathrm{SOH}$ & 1 & 0 & 0 & 0 & 0 \\
$\mathrm{SOH}_{2}^{+}$ & 1 & 1 & 0 & 1 & 7.2 \\
$\mathrm{SO}^{-}$ & 1 & -1 & 0 & -1 & -9.5 \\
$\mathrm{SOPO}_{3} \mathrm{H}_{2}$ & 1 & 0 & 1 & 0 & \\
$\mathrm{SOPO}_{3} \mathrm{H}^{-}$ & 1 & -1 & 1 & -1 & to be fitted \\
$\mathrm{SOPO}_{3}^{2-}$ & 1 & -2 & 1 & -2 & \\
$\mathrm{H}^{+}$ & 0 & 0 & 0 & 1 & 0 \\
$\mathrm{OH}$ & 0 & 0 & 0 & -1 & -14 \\
\hline
\end{tabular}

1) The values are known for $\gamma$-alox in the medium $\mathrm{NaClO}_{4} 10^{-1} \mathrm{M}$, namely $11.1,6.1,-4.4$, and were adapted for the chosen boundary conditions changing each value by the same amount of $\Delta \log \mathrm{K}$ (see appendix IIb) to fit observed o- $\mathrm{PO}_{4}$.

\section{Appendix II}

a) Matrix for calculating species distribution in the systems $\gamma$ alox $/ \mathrm{Cu}^{2+} / \mathrm{Zn}^{2+} / \mathrm{NOM}$ and $\mathrm{Bg} / \mathrm{Cu}^{2+} / \mathrm{Zn}^{2+} /$ NOM.

\begin{tabular}{lllllllll}
\hline & $\begin{array}{l}\text { Components } \\
\text { Species }\end{array}$ & $\mathrm{SOH}$ & $\mathrm{e}^{-\frac{\mathrm{F} \psi}{\mathrm{RT}}}$ & $\mathrm{H}_{2} \mathrm{X}$ & $\mathrm{Cu}^{2+}$ & $\mathrm{Zn}^{2+}$ & $\mathrm{H}^{+}$ & $\log \mathrm{K}$ \\
\hline 1 & $\mathrm{H}_{2} \mathrm{X}$ & 0 & 0 & 1 & 0 & 0 & 0 & 0 \\
2 & $\mathrm{HX}^{-}$ & 0 & 0 & & 0 & 0 & 0 & -2.8 \\
3 & $\mathrm{X}^{2-}$ & 0 & 0 & 1 & 0 & 0 & -2 & -16.2 \\
4 & $\mathrm{SOH}$ & 1 & 0 & 0 & 0 & 0 & 0 & 0 \\
5 & $\mathrm{SOH}_{2}^{+}$ & 1 & 1 & 0 & 0 & 0 & 1 & 7.2 \\
6 & $\mathrm{SO}^{-}$ & 1 & -1 & 0 & 0 & 0 & -1 & -9.5 \\
7 & $\mathrm{SX}^{-}$ & 1 & 0 & 1 & 0 & 0 & -1 & $31)(2 \mathrm{mg} / 1)$ \\
8 & $\mathrm{H}^{+}$ & 0 & 0 & 0 & 0 & 0 & 1 & 0 \\
9 & $\mathrm{OH}^{-}$ & 0 & 0 & 0 & 0 & 0 & -1 & -14 \\
10 & $\mathrm{Cu}^{2+}$ & 0 & 0 & 0 & 1 & 0 & 0 & 0 \\
11 & $\mathrm{CuHX}_{12}$ & 0 & 0 & 1 & 0 & 0 & -1 & $\left.4,5^{2}\right)$ \\
13 & $\mathrm{SOCu}^{+}$ & 1 & 1 & 0 & 1 & 0 & -1 & -1.4 \\
14 & $\mathrm{SXCu}^{2+}$ & 1 & 0 & 1 & 1 & 0 & -1 & $\left.10.8^{3}\right)(2 \mathrm{mg} / 1)$ \\
15 & $\mathrm{SOZn}^{+}$ & 0 & 0 & 0 & 0 & 1 & 0 & 0 \\
\hline
\end{tabular}

1) The $\mathrm{K}$-value depends on $\{\mathrm{P}\}(2 \rightarrow 16 \mathrm{mg} / \mathrm{l})$ because the surface coverage is very close to saturation.

2) Adapted from Baccini [2].

3) $\log \mathrm{K}_{13}=\log \mathrm{K}_{11}-\log \mathrm{K}_{2}+\log \mathrm{K}_{7}$. If $\mathrm{Cu}^{2+}$ does not influence the sorption of $\mathrm{H}_{2} \mathrm{X}$ (see chapter 4.2) the free energy of the reaction $\mathrm{Cu}+\mathrm{H}_{2} \mathrm{X}+\mathrm{SOH}$ is equal to that for reaction 7 . 
b) Matrix for calculating species distribution in the system ( $\gamma$-alox $\left./ \mathrm{H}_{3} \mathrm{PO}_{4} / \mathrm{NOM}\right)$. Species No.1-9 as in Matrix IIa) with components of b)

\begin{tabular}{lllcllll}
\hline & $\begin{array}{l}\text { Components } \\
\text { Species }\end{array}$ & $\mathrm{SOH}$ & $\mathrm{e}^{-\frac{\mathrm{F} \psi}{\mathrm{RT}}}$ & $\mathrm{H}_{2} \mathrm{X}$ & $\mathrm{H}_{3} \mathrm{PO}_{4}$ & $\mathrm{H}^{+}$ & $\operatorname{logK}$ \\
\hline 10 & $\mathrm{H}_{3} \mathrm{PO}_{4}$ & 0 & 0 & 0 & 1 & 0 & 0 \\
11 & $\mathrm{H}_{2} \mathrm{PO}_{4}^{-}$ & 0 & 0 & 0 & 1 & -1 & -2.1 \\
12 & $\mathrm{HPO}_{4}^{2-}$ & 0 & 0 & 0 & 1 & -2 & -9.2 \\
13 & $\mathrm{PO}_{4}^{3-}$ & 0 & 0 & 0 & 1 & -3 & -21.6 \\
14 & SOPO $_{3} \mathrm{H}_{2}$ & 1 & 0 & 0 & 1 & 0 & 9 \\
15 & $\mathrm{SOPO}_{3} \mathrm{H}^{-}$ & 1 & -1 & 0 & 1 & -1 & 4 \\
16 & SOPO $_{3}^{2-}$ & 1 & 2 & 0 & 1 & -2 & -6.5 \\
\hline
\end{tabular}

